\title{
A Didactic and Methodological Lesson of the Study of Economics and the Skill Development of Students
}

\author{
Maria Covadonga De la Iglesia Villasol \\ Complutense University of Madrid, \\ Spain \\ "...The complexity of models is elaborated merely for display, \\ far and away beyond the possibility of application to reality ", \\ Joan Robinson (1979) ${ }^{1}$
}

\section{Introduction}

The consolidation of the European Higher Education Area (EHEA), into which many European Universities have thrown themselves, especially Spanish Universities, means for many senates the revision and the methodological adaptation of the contents to be taught and professors' work in the new Bachelor's degrees. The piece of work presented is a reflection on some methodological aspects of how to tackle the teaching/learning process in the study of Economics and, for this purpose, it rescues some lessons by important scholars, especially those by lecturer Joan Robinson. Works by Joan Robinson are innumerable; her legacy in the study of economics and social sciences does not limit to her great work The economics of imperfect competition, but it covers different topics as the diffusion, spread and explanation of master Keynes's contributions, since she was one of his young disciple and was part of "Circus", or, for many, her great contribution The Accumulation of Capital, written in 1956 (check Iglesia, 2007, for a summary).

The starting point to face the proposed aim is to reopen the famous box of tricks with which we, the economists of the latest generations have been trained, under the didactic approach, in order to assess once again its use in the current world; a world which is ever-changing, more and more open and dependent on new technologies and which points out the learning by doing concept as the guiding principle to follow; a world in which interdisciplinarity is becoming more important in the learning and in the work environment into which graduates must enter and in which cooperation between disciplines, which are close in the arch of knowledge, provides a greater degree of creativity when addressing the analysis and the search for solutions to the more and more complex economic problems, a search done by society and its institutions. In fact, any authors have stated that the solution to the current economic crisis should come from sociocultural fields, not only from economic ones.

${ }^{1}$ Cited in Walsh, V. y Gram, H. (1980), p XI 
New technologies have developed both new and changing teaching/learning spaces in which professors almost always lag behind their students. This is because students were born in the generation of both the incorporation and expansion of computing in learning, professional and leisure environments and the development of new ways of synchronous and asynchronous relations, of search and selection of the vast amount of freely available information, and even the establishment of rules of conduct and, in short, new models to which professors must adapt and, where appropriate, develop a range of abilities/ competencies/skills for which they have not been trained. In this sense, Gilbert (2001) states in an interesting text that professors need to assume the roles of information consultant, team collaborator, facilitator, lone worker, resource provider and academic supervisor in this technological age. These roles complement the mentor of writing (provider of feedback to the pieces of work done by students) and orchestrator (because he performs administrative, pedagogical, technological and link functions) pointed out by Wake, Dysthe and Mjelstad (2007).

Therefore, this article tries to address some of the aspects related to the didactic action of economics, following certain works by Professor Robinson where she showed concern, particularly in the last years of her academic life, for methodological aspects and the future of the study of the economic analysis and economics. Some of her statements prove it and are, at least, thought-provoking and often a source of controversy. Examples of this can be found, for instance, when she states that economic theorists of the last fifty years have been more concerned about the training and propagation of ideology than about the understanding of the world we live in, submerged in different arguments and moral values (statement referred to the controversy about the capital measurement The relevance of economic theory, published in Monthly Review, 1971). She even states that logic is corrupted by opinions, and she also writes in another piece of work that economists have abdicated to sociological and psychological views in explaining those issues that concern them (in Economics Today, lecture given in December, 1969 at the University of Basel accumulated in Collected, 1973). These and other fragments rescued from her innumerable writings are the guide of the methodological lesson tackled in this piece work, which explains how to review the teaching and learning process of economics in a context where the principle of learning by doing is vital. Therefore, this article will not question the specific contents of the studies in economics, nor is it to deal with some of the reviews which have generated interesting "controversies" in which leading academics have highlighted some theoretical inconsistencies in the patterns of economic thought in the modelling. On the contrary, it will collect and review some of the lessons that are either valid or adaptable to the current educational context.

Thus, it is important to state that the necessary methodological revision brought by the Bologna Process (Bologna Declaration in 1999 on the European space for Higher Education, EHEA, ratified by 32 countries in the Prague Communiqué, 2001), based on how to redefine the calculation of the ECTS (European Credit Transfer System) credits and the extra effort for professors and students of a teaching focused on the learning, has to strengthen the bases for a solid improvement in the quality of teaching. This revision has to be done through the updating of contents and the development of different activities and teaching resources that let students gain knowledge and skills that are specific in their degree during their training, while developing the transverse, systemic skills (as the Tuning Project refers to them) that the multidisciplinary, globalized work environment where they will practice their profession demands increasingly. 
In this respect, it is worth considering some empirical studies on the level of development of skills of graduates and students enrolled in either Economics or Business Management degrees (ECO and ADE are, respectively, the acronyms used in Spanish). These degrees show clear mismatches between the requirements of the labour market of professionals with high levels of competence and the degree of development acquired during their university training. Such mismatches vary depending on the previous professional experiences, expectations of the graduates or students and, therefore, on their degree of familiarity with the work environment in which they enter. It might be because they have usually done an internship or because they have had previous temporary jobs, or they have completed part of their degrees abroad by means of the Erasmus programme. Differences in the assessment of the importance of skill models between academic and labour field have been found in other studies with different analysis methodologies, objectives and samples. These results, which should be a reflection and a self-criticism, may be related to the way the didactic action has been addressed for a long time. It has focused on learning through the memorizing of mere concepts usually away from practice and simulated professional environments. The results show how to incorporate those activities to increase the skill development of our students in both the active learning process and its continuous evaluation.

This essay provides a symbiosis between some of the thoughts of various authors within the field of social sciences in general and Economics, dealing also with some of the trends and challenges faced by the European University nowadays, which are marked by internationalization and multidisciplinarity. It also alludes to the need to respond to the real, changing, global problems of society with fully qualified professionals both in content and specific competencies of their qualifications, and also, in a very special way, in generic, systemic, transverse and even emotional skills that favour a successful inclusion in the labour market. This approach to a quality teaching action, appropriate to the technological age and needs of today's society, is a real reform, desired by many, and it transcends the "Bologna Process" itself, which requires a commitment from academic authorities, business organizations and senates in which the actors and the primary beneficiaries are the students themselves, as they are the human capital of future generations.

Therefore, the chapter consists of the two marked parts: a guided methodological reflection on didactic action and a revision of empirical aspects related to the levels shown by graduates/students towards skill development within areas dealing with Economics.

\section{Some methodological considerations for the study of Economics}

Obviously the current University is a reflection of the society in which we live and there are remarkable differences with the one where some of the great masters of economics went to. This is mainly because of the use of technology in the teaching-learning processes, in the classroom and outside it. It can also be because of the way students mix themselves with professors, the way of searching the necessary information to enjoy themselves, etc. The technological revolution framed in a change of curricula adapted to the EHEA, has been the opportunity and/or the reason for professors to seriously reflect on how to address the specific contents of the degree.

That is, a reflection on both those specific contents that graduates should acquire and the methodological aspects of their study that otherwise would almost certainly be beyond our immediate interests. In this new methodological framework, the teaching work is increasingly 
done in a diverse educational context, where professors are not only a mere expert in content designed for oral presentation in master classes, but they also become designers of new learning environments. Professors combine and use a variety of educational resources and techniques and, at the same time, they become a generator and evaluator of useful resources for self-learning. Furthermore they also embody the necessary and fundamental aspect of being counsellors, mentors, motivators, and co-learners of their profession. They effectively teach the content and the subject to their students for their future professional development, that is, they are companions in the learning process as Iglesia (2006) stated.

But referring again to Cambridge and Professor Robinson, who makes us think about some methodological aspects of the study in today's economy, it is worth noting her unceasing interest in the study and the modelling of microeconomic problems when she said that "in my young days the trick was worked by concentrating on micro problems"... (in the essay "Marginal Productivity", published by The Indian Economic Review, 1976 and accumulated in the work Collected, 1973, cited by many authors). This ability has been, is and will be necessary to understand how the stylized economic models and the interrelationships among the relevant variables work. Both are necessary to make predictions about the behaviour of agents and future expectations and to specify explanatory equations in empirical analysis studies. This is then the main purpose of the article: to reflect on Joan Robinson's box of tricks. These tricks allow us to model the behaviour of agents from restrictive, simplifying assumptions, or skills, because their use makes it easier to deal with the learning of the interrelationships between the relevant economic variables. Thus, our students should definitely learn to use these tricks, which are a method of analysis and $a$ way to think like economists to solve problems of this increasingly complex, globalized economy. It has been 50 years since Joan Robinson showed their know-how through the classrooms. Although we have undergone a severe methodological change, some aspects should not, cannot change the study and the learning of Economic Analysis, such as the deep knowledge of the essentials that tighten up and support economics. But this statement does not preclude that such learning fits the current and unpredictable future development of the Information Technology (IT), as the UNESCO Universal Declaration on Cultural Diversity (Article 1) states. It refers to all disciplines and hence is applicable to economics, since it considers innovation and creativity to be a source of the change. Both are beneficial for present and future generations, and for whom IT has transformed the perception, the lifestyle, the way they communicate and the learning tools of an increasingly higher part of the population. Following this theory, when referring to the main method of thought and study of economic theory in the text Essays on Economic Analysis (1964, Exercices in Economics Analysis, in 1960), a pleasant to read book for any professor from this field, whose validity is timeless, Robinson describes it as "a model of construction", which "consists in a very simplified mental picture, which shows the behaviour of people in a social and physical environment, and eliminates what is not essential to the problem of the day, the way of focusing attention on what is essential" (1964, p. 10). In this regard, she points out some methodological rules to observe in the systematic study of economic theory, which, being basic, are often forgotten or simply not specified: 1) to consider the time variable in the analysis, 2) to specify the units used to measure the variables so that the different amounts have a meaning and 3) to distinguish the technical and physical relations between a human being and nature and between two human beings (1964, p. 7). Regarding to the time influence in the economy, as Carpintero says (1999, p. 137-38), Robinson states in 1953 in the essay Lecture in Oxford by an economist from Cambridge that "the distance between today and yesterday is 24 hours when we 
advance, but an eternity when we move back", but in 1975, in the article "The Time in Economics", in an homage to Georgescu-Roegen, John Hicks talks about the incoherence of representing the time in an economist's blackboard as it was a space, since, although ... "we can move in the space in any direction, the time only advances, it does not move back". Thus, Joan Robinson sets out the steps for students to "... learn something by doing it", and she shows to the readers "how to get to the propositions in economic theory, so they can continue by themselves from the point where the book ends" (1964, p. 7). She says it in the prologue of the quoted text, written in 1959 (published in 1960), and which, as she alleged, is "an uncommon book" (at prologue 1964, p. 7). In this book where she recommends "to use (referring to the suggested exercises) as a basis for group discussion", since she believes that "each student must work on an exercise and then compare the results with others and discuss their meaning and application" (p. 7): un approach distinguished from the common practice in our classrooms where the student resolves the exercise and checks the solution, taking the first of the steps suggested by Robinson, both for her comfort or, in many cases for the teacher's comfort. The fact that it is an unusual text has also been reflected in their methodological approach, in which she highlights the almost total absence of mathematical and graphic symbols (in a 299-page book there are exactly only 9 simple equations and no graphics), wanting to reflect, perhaps, what Joan Robinson once said ¿or was attributive at her? "I do not know mathematics, therefore I have to think" (if we check her more than 100 published works, it is easy to state that this statement is false). This phrase is often quoted by students of Economics when they criticize the difficulty of addressing the learning of abstract theoretical models. Although this phrase seems opposed to the common practice in standard texts of Economic Analysis and collects tradition expressed by Koopmans (1957) when he states that perhaps the numerical example and the diagram are the oldest mathematical tools in economics, it is perfectly compatible with it, since the mathematical formalisation allows styling and modelling the interactions of economic variables, providing the scheme of thought in which the reflection, the evaluation and the study are supported, without the need of being written.

Note that these suggestions recommend considering some basic, transversal skills that the student must develop in the learning process of economic theory, such as the ability to synthesize and to analyze, oral presentations, critical discussions or teamwork, etc.

Some of the tools of analysis are retrieved and analyzed. They are necessary to progress in the teaching-learning process of the behaviour of economic operators and the basic functioning of the models supporting economics, and they should be adapted around today's technology.

\subsection{On the subject of mathematical economics and multidisciplinary analysis}

These pages are not meant to reopen the discussion of the use/abuse of mathematics in the study of Economics (we take Frank Hahn's advice for the youth taking his baton: as it was a plague, to avoid discussions about Mathematics in Economics, quoted in Streeten, 2007, p. 49), they just collect some quotes for the critical reflection on some methodological aspects of the theoretical modelling and its abstract approaches. Whereas Samuelson (1947) stated that mathematics is more than a language, it is also a "powerful" tool for the solution to some central problems of Economics, Joan Robinson (see Walsh and Gram, 1979, in introduction pages) argued that "...the apparent precision of Mathematics has generated imprecision. The mathematical operations are performed on entities that cannot be defined, the calculations are made in terms of units that cannot be measured, correlations are confused with occasional laws, differences are identified with changes.... The complexity of models is made just for display, far away from the 
possibility of applying it to reality". Because of its abstraction, the virtue of mathematics is an accepted and not arguable fact in the economic analysis to state exactly and precisely the generic objectives of the economic operators and the axioms and decision criteria and restrictive assumptions and simplifications of reality that frame or define the context of the analysis, deductions and conclusions of models. However, the excessive use of formulation and mathematical symbols can have some risks if it confuses the student and it does not clarify the exposure and/or research. And this is out of the controversy, never close enough, of the realism of the assumptions of the economic analysis, since the results of the models are only valid in the compliance with the postulations made. Therefore, the use of mathematics in deductive method of the economic analysis makes explicit the assumptions of the models.

The current box of tricks combines classical analytical instruments, such as the numerical example, the mathematical symbols, the diagram, quantitative methods, with some more sophisticated and powerful utilities, expanded by the development of virtual technology, whose teaching virtues have widespread providing new media, ranging from the interactive whiteboard, tablet PC, virtual learning environments, simulation platforms, Web 2.0, etc.

We have gone from white chalks to laptops both in the teaching and in the learning of each of the pieces of the puzzle that the economic reality is and that at the same shapes the Economic Theory. Once they are analysed, these pieces must fit together perfectly to set up the studied reality and to give answers to the economic problems that society is facing. In this regard, Joan Robinson, when justifying the proposed method, points out in the already mentioned text, Essays in Economic Analysis (1960, in introduction pages), that "we must first divide the question into parts, and discuss each one separately, and piece them together again as best we can". Today the availability of a powerful mathematical programming software supports the analytical modelling of such pieces and the simulation of real environments and various scenarios of economic policy, which are increasingly used both to study the comparative statics and to determine the economic forecasts and its future projection. Different international public organizations and important study centres have been developing sophisticated simulation models for more than three decades in order to, for instance, predict the behaviour and development in different countries and to check possible imbalances in the same, or the effect on the saving, the private consumption or the investment of a change in the marginal tax rate. Although the term simulation may have several definitions, which could be summarized in exploring the behaviour of an experimental or virtual model similar to the real one in order to understand and/or predict its path, there is no doubt that it is a method that generates scientific knowledge and it is also a tool for learning how the economic reality works, which is studied through basic theoretical models. According to the paradigm of the study of Economic Analysis, we only understand an economic fact/phenomenon when we know the theoretical model that reproduces it, that is, when the interaction of behavioural assumptions that are set and the assumptions that define the scope of the problem/model, determine outcomes. Being this the case, simulation is hence a tool in the learning process of a changing world, plunged in a context of uncertainty.

This tool of simulation is not new and it has boosted its use with the technological development and algorithmic software, increasingly framed in virtual spaces, which also facilitates the integral view of teaching and learning in the economic analysis, materialized in the use of electronic didactic resources, which are available on Internet, and characterized by being: 1) radial, usable in different training levels, 2) multidisciplinary, since they address topics from different areas, approaches, methodologies and fields, 3) geared to the 
summary of the theoretical models with practical developments and uses in a professional environment and 4) updated, as Gracia and Iglesia (2007) point out. It thus builds a network of interrelated content that facilitates the student to approach Economics from different perspectives: theoretical models, empirical applications, case studies, actual experiences, the basic study of comparative statics of equilibrium and its implications in public policies, economic indicators, or historical references, etc. This integral, radial and multidisciplinary vision of the learning in economic analysis makes students learn to "think like economists" and develop certain skills that are needed in the economics' workplace. Students have rarely been developed them with the traditional teaching methodology.

Regarding this vision, in today's globalized world, there can be economic problems of other disciplines, as interdisciplinary boundaries are increasingly permeable so that they make intersections that go far beyond what our old masters could imagine half a century ago. Some examples are the Economics of education, environmental economics, economics of health, of natural resources or experimental economics whose development began in the investigation and later turned to teaching. Thus, Streeten (2007) identifies three reasons, with different methodological implications, that justify the disciplinary or interdisciplinary work, that can be moved to the learning process of students of economics: 1) the specialists of different disciplines, when working together on a single problem, in a cooperative way, contribute to the more complete and richer integrated solution, 2) certain assumptions, concepts, methods or techniques, when applied to other disciplines, may provide useful or satisfactory explanations and 3) it is possible that the approach of a separate discipline is not valid in a time or in a region, due to interactions between economic, social, political, historical variables, or the institutional knowledge (see the various examples he gives about interdisciplinary studies on Economics).

The fact that current economists work beyond the traditional borders in economics and with multidisciplinary approaches does not imply, as Streeten argued in the quoted text, the strengthening of other disciplines for the Economy against the opinion of Hicks (1979) (quoted by Carpintero, 1999, p. 129) who said that "the field of phenomena with which economics deals is so tight, that economists are continually banging their heads with their limits", generating new knowledge, the result of "riding cheerfully certain academic borders", the ones to which Dumont (1982) refers (quoted by Carpintero, 1999, p. 129). What it implies is that the new transdisciplinary knowledge searches intersections between different disciplines, absorbing background knowledge and taking advantage of permeable classic borders. In this point, it is necessary to refer to Georgescu-Roegen, who according to Zamagni (1986, p. 516), and although "his message has the peculiarity of not being identified with any school of economic thought", his intellectual aid in this century can be seen as "...the main contribution to cross the frontiers of economic theory and methodology". Later on, Carpintero (1999), and regarding this transdisciplinar focus, added that it is located at the base of the review performed by the Romanian economist of the mechanistic basis of the conventional economic approach, which not only affects the level of consumption, but also the level of production, and for this to be done, he was based upon the teaching of some subjects from the natural sciences such as thermodynamics and biology.

To strengthen the current relevance in the different areas of the science of inter/multi/transdisciplinarity mentioned (the semantic differences between the tree terms are clear, although they are usually used indiscriminately), there has been some clear examples, such as the Border Intramural Project initiated in 2004 by the Spanish National Research Council (CSIC) 
whose aim was to promote the incursion of scientists into new themes emerging from the interaction of several areas of knowledge (for instance, see the call for grants of the 10th of June of 2006), or the revision of the thematic lines of international conferences that show the relevance of multidisciplinarity in all areas of science. Another example is the final text of the Seventh Framework Programme of the European Community for research, technological development and demonstration (2007-13), which specifies that "it will strengthen the excellence ... through cooperation programmes, ideas, people and skills", and that includes some of the amendments proponed (documents: PE 360.033v010-00, amendment 312 presented by Rübi, P. -appendix I, paragraph 1- and PE 360.033v010-00, amendment 332 presented by Niebler, A. appendix I, chapter I "Cooperation", paragraph 6), in which reference was made to the relevance of interdisciplinary and multidisciplinary studies, quoting the European Union Research Advisory Group, which reports in its Indisciplinary in research (EURAB 04.009, April 2004 ) that the interdisciplinarity "is essential in keeping Europe at the forefront of scientific and technological research. Interdisciplinary research is a necessary feature of progress in scientific exploration". Moreover, it reports that in the field of "scientific cooperation", the promotion of such "joint calls" will provide new impulses and ideas, as "it is precisely in the boundaries between disciplines where knowledge and brand new products emerge."

In this sense, professors should not be away either from the economic, social and cultural development around us, or from the nearest scientific community, or from technological progress and its applications in learning, or from new and emphatic forms of media and entertainment which are suitable for learning, thus reformulating the teaching task, which is in a continuous process of adaptation to the environment, needs, perspectives and technology.

\subsection{About discussions, the creation of knowledge and independent learning}

It is worth returning to the discussion of those pieces of work to which Joan Robinson referred as a tool of learning. It is also worth pointing out that in the history of the economic thought there have been many episodes of scientific debate and controversy among the different positions or schools, which have promoted the progress in the development of theoretical models, without being alien to -the "unavoidable"?- ideological influence. If it was advisable not to enter the debate on the use/abuse of mathematics in the study of Economics, it is even more advisable not to enter the ideological presence in the approaches and orientations of economic problems.

Professor Robinson should be referred again, especially her book Economic Philosoph (1964), when dealing with the influence of ideology on economics. Robinson gives an answer to the question of determining the "criteria of an ethical proposition opposed to the criteria of a scientific proposition". She states that "if an ideological proposition is treated in a logical way, it may be dissolved in meaningless junk, or it may be a circular argument." These two metaphysical propositions still have their content and, "although they do not belong to the field of science, they are necessary for it", because they "have played a role, even an indispensable one," at least in the social sciences. She also adds that "although the ideology may or may not be removed from the world of thought in the social sciences, in the real world ... is certainly indispensable," ... and that "every economic system requires a set of rules, an ideology to justify them, and an awareness of the individual that makes him/her strive to fulfil them" (see pages 7-9, 18 and the following ones). It is very important to remember that debates in any science, especially in economics, have generated knowledge 
through logic considerations and conclusions. Therefore it is a good idea to expose students to a creative learning process from debates as a useful tool for searching a new knowledge. For this purpose, the debates need to be guided, thought, meditated and experimented by the professor. Regarding the use of debates, both in the generation of knowledge and in the progress of learning, Joan Robinson refers to them in the previously quoted text, Essays on Economic Analysis (1964), when she recommends "to use the exercises as a base of a team debate" (see introduction pages, p. 7). For this to be carried out, the professor should learn how to reformulate the standard exercises that make it easier to understand the models, and how to complement them with the incorporation of a set of open, well-defined questions. It is worth noting the difficulty of students when reviewing and answering coherently questions such as: what is the objective?, how is it interpreted?, what does it provide?, how is it related to?, etc. These questions should lead the student to create a new knowledge, to discover new concepts which have not previously been taught in the classroom and to go beyond what the professor has explained in class. Thus, Robinson believes that "the first step in the practice of the analysis is to learn how to know what a debate is about" (p. 13). This is why, it is very important to choose the questions so that students make progress in their knowledge and, as our mentor does throughout the above mentioned text, the professor can lead, advise and help each person to find which their own standard of judgement is.

It would be a mistake to stay in the lexicon and in the vehemence debated by several schools, which are not an end in themselves, but a way both for the process for creating knowledge among the academic ones of a discipline and for the active learning process of our students. For this purpose, some rules of the dialectic game should be set in motion; a game to which they (or even we) are not often used to and which is required as a transversal skill in any professional environment. It would be equally important to promote the search of important information to tackle any particular topic and to be critically assessed. In order to make the debate a useful way to learn, students should formulate clear questions to themselves for the search of answers. This is the only way to encourage the autonomous learning. In this sense, the quote by Isaac Rabí, Nobel Laureate for Physics in 1944, is very revealing. He affirms that when he came back from school, his mother would ask him the same question: "have you asked a good question today?" (In Szenberg, 1994, p. 5). It would be appropriate to add that Joan Robinson herself was a clear example of activism in her time in the construction of knowledge resulting from debates and discussions in every format possible. This activism went from written correspondence, meetings or seminars, to scientific essays. She was also part from, and sometimes she even provoked and provided feedback for, the most famous and scientific controversies in the economic field. As a historical note, it is worth pointing out that, from 1931, Joan Robinson was part of the Circus, together with her husband Austin, Sraffa, Harrod and Meade, whose aim was in to analyze Treatise on Money published by Keynes in 1930. She opened a deep debate when discussing with the master some elements of the General theory before its publication and she had with him a long, productive correspondence, more than 137 letters from April 1932 until April 1947, after the publication of the works Treatise on Money and A parable on saving and Investment. Furthermore, she was also in correspondence with authors such as Khan or Kalecki, since it was a very common practice among scholars from that time.

Regarding these disagreements, she stated that participants in these controversies are divided into schools -the conservative and the radical school- and the ideology seems to ooze in the logic. In economics, arguments are devoted, as in theology, to hold doctrines 
more than to test hypothesis (Robinson, 1977). Apart from that, she also reiterated that economists cannot resort to controlled experiments, as other scientists do, and the only way to have access to reality is by (means of) historic evidence; and most of the times that evidence could be read in both ways: the conservative and the radical one.

The written correspondence with other partners was a widespread way of discussing. This has nothing to do with today's society, where this activity has been relegated to the immediate email, which is very useful for the communication between students and professors so to solve doubts. In many cases, it is supplemented with thematic forums separated by categories, by topics within a subject and feasible with the methodology of e-learning platforms, virtual campus of the university, forums, personal blogs, wikis, etc. Everybody knows that the massive use of the different virtual resources is opening the catalogue of professions and there are, for example, bloggers that give a qualified opinion about several social, political and sports topics. These bloggers also comment on the new trends and what the latest news are, they open discussions, mobilize people and they are able to organise thousands of followers on a particular way of thinking or behaving so that they can set goals and vindicate them in a highly linked society that is developing very vague channels of communication.

Going back to the importance given by Joan Robinson to the political debate as a generator of knowledge, and referring to the controversies among academics, she states that debates should lead to an agreement, since the rules of logic and the available proof are the same for everybody. Moreover she points out the five reasons that, according to her view, set the starting point of a controversy (Introduction to the Theory of Employment, 1937): 1) The participant cannot make their opponents understand their point of view; 2) Any of the parts has made a logic mistake in the reasoning; 3) Participants assume different suppositions; 4) There is not enough evidence to clarify or to empirically contrast any aspect, and 5) The ideology of the participants is different.

These elements should be taken into account in the teaching/educational use of debates, since students should acquire knowledge and, therefore, they should justify their points of view, using logic and reasoning supported by known and, in many cases, mathematical material. They should specify the restrictive assumptions of the model supporting the presented arguments, giving different evidence. Therefore, they should be creative when searching and block out from the starting ideology. In short, this work is to make us think about the education that an economist, a good one, should obtain. In relation with this, Streeten (2007, p. 40) argues that the economist "will be better theorist if he knows philosophy and a better economist if he knows political science and history". He agrees on supplementing the use of the basic tools of economic analysis with the study of other adjoining disciplines such as history, the economic institutions, the elements of politics, etc. Furthermore, he points out that "education is more than acquiring skills and aptitudes, but also acquiring attitudes", and he also wonders about the limits: "what shall we do in order to make (students/graduates in Economics) properly use the toolbox with which we equip them so that they avoid being victims of the law of the hammer...? (the law of hammer is that law according to which a little boy, given a hammer, finds everything worth pounding, not only nails but also Ming vases) (Streeten 2007, p. 41). This is the question that leads us to the following section: to delimit how the learning and teaching processes should be reflected in the skill development of our students, taking their subjective perception to answer the required challenges in the working environment that they will enter, or they have already entered. Issues, those before mentioned, related to different indicators of educational quality. 


\section{From the theoretical training to the skill development}

Many readers may see a huge somersault between the two sections of this piece of work, but this happens only when the author cannot define clearly the conducting thread between them. In other words, the reader must be shown how important is to convert the methodological aspects mentioned above about the teaching/learning of the economic analysis, guided by some quotes from Joan Robinson's works, into a satisfactory skill development of the students. This development should meet the needs of the uncertain, changing, globalized, complex social and economic environment surrounding us.

The first test to be passed is the establishing of the generic concept of the word skill, a concept which is quite diverse, elastic and flexible because, as Climent (2010) states, though these several terms are often used without distinction, they are not always synonyms and some of them have important conceptual differences between them. This happens, for example, with the words abilities, dexterity, skills, qualities, aptitudes and/or talents, mainly when the Competence-Based Education school appears (the different definitions and typologies included in it are very instructive; they let laypeople delimit the concept and establish several dimensions of it). In order to delimit the point of view from which this work is based, in accordance with Holmes (2000), ability is a causative tool of what a person does, inside or outside the labour or social reality where this person lives, while skill is the ability that lets a person use a set of skills, knowledge and values in a suitable way in order to perform a task successfully, in certain labour or social circumstances. In line with this, Sladogna (2000) talks about complex abilities that have different degrees of integration and that appear in a wide range of situations in the different aspects of the personal and social human life, as these abilities are a synthesis of all the experiences the person has undergone in the frame of his past and present personal environment.

Thus, through the pragmatic way followed in this piece of work, and given that the author is not an expert on this subject, skill could be defined as "ability obtained through the combination of the knowledge with the social environment and personal characteristics, the aptitudes and experiences, which professionals, in this case university graduates, must have in order to perform their professional responsibilities in their jobs". Some of the elements of this definition are remarkable as it integrates the knowledge, gained in the process of the teaching-learning, with environmental, social and personal characteristics, but also from their own experiences. For more information about the theoretical development of the skill models, consider scholars such as McClelland (1973), Spenser and Spenser (1993), or LévyLeboyer (2001). However, the guide that has been used in the empirical piece of work that is presented below is more similar to the institutional models in which the REFLEX study (Aneca, 2004) and the Tuning project (see González and Wagenaar, 2003) were carried out.

\subsection{Empirical approach to the skill development of university graduates in the area of Economics}

In the following pages certain empirical evidence is presented in a descriptive way. It relates to the already proved phenomenon of the existence of clear imbalances between the perception university graduates have about the degree of their skill development and the assessment they make about how important it is in the working environment. This is 
obtained from the subjective points of view of students, from their own social, work, personal experience and from the learning environment in which they have been brought up. This fact confirms the positive effect of the work experience in the reduction of the gap observed.

This empirical approach here included shows how important is to improve the skill development among students during the university training process, which should go hand in hand with a specific technical training in each particular degree. This empirical approach gathers data collected from an opinion poll conducted on students in their fourth and fifth year of the Administration and Business Management [ADE] or Economics [ECO] degrees, which are taught in the Faculty of Economic and Business Sciences of the Complutense University of Madrid (UCM) and Alcalá de Henares (UAH), in January 2010. It should be explained that although the selection of the years, the fourth and the fifth, may bias the results obtained. This can be justified, however, since students in those years have already more precise criteria about the working environment. In fact, most of them were doing an internship or had already done one. They also had previous work experience and therefore they were able to determine if having previous work experience improved the skill development among university graduates, a fact that can justify certain reorientations of the training plans when designing the aim and the scope of the practicum.

The opinion poll used in the empirical analysis contains a comprehensive list of 40 standard skills, considered as independent variables. The questions related to different skills are presented in two symmetric groups, one refers to the skill degree developed during the university training (_UT) and the other one to the importance students think it has in the working environment in order to carry out their professional activities (_IW). Students assigned a numerical evaluation using the Likert scale, from 1 to 5 (1= strongly disagree and $5=$ strongly agree).

As a summary,table 1 below describes the population who participated in the opinion poll and from the 444 of those polled who were attending classes on site, $49.55 \%$ of them were men, and $42.57 \%$ were in their fifth year, $34.45 \%$ of them studied ECO and $65.31 \%$ of them stated they had previous professional experience. There are not significant differences between the subsamples of the two universities (UCM and UAH). Furthermore, in ADE, $50.86 \%$ of the students were men and $47.06 \%$ were also men in ECO, $47.45 \%$ of the students enrolled in fourth year are men. This percentage is higher in the fifth year as $52.23 \%$ of the students were also men. Among the students that stated they did not have previous working experience, the percentage of men was $55.19 \%$ while the ones who had previous working experience dropped to $46.55 \%$. This fact shows that women are relatively getting closer to the working environment during their academic training.

It can be concluded from the descriptive analysis that, as the table A1 of the annex shows (for more details see Iglesia and Ionita, 2010), when students were asked about the degree of skill development during their university training (_UT), the more representative option was "average", with percentages between 27 and $40 \%$, and it turned to "very much" regarding to the degree of importance of the skills in the working environment in order to carry out their professional activities (_IW), with percentages that ranged from $32 \%$ to $50 \%$ with exceptions when students chose mainly the intermediate option (that is, a 3). This 


\begin{tabular}{|c|c|c|c|}
\hline $\begin{array}{c}\text { Administration and Business Management degree (ADE): } \\
65.5 \% \text { to sample }\end{array}$ & \multicolumn{2}{c|}{ Economics degree (ECO) } \\
\hline Men & $50.86 \%$ & Men & $47,06 \%$ \\
\hline \multicolumn{2}{|c|}{$4^{\text {th }}$ year: $57,43 \%$ of the sample } & \multicolumn{2}{|c|}{$5^{\text {th }}$ year } \\
\hline Men & $47,45 \%$ & $52,23 \%$ \\
\hline Without professional experience (_S): $34,68 \%$ of the sample & $\begin{array}{c}\text { With professional } \\
\text { experience (_C) }\end{array}$ \\
\hline Men & $55,19 \%$ & Men & $46,55 \%$ \\
\hline
\end{tabular}

Source: Personal Compilation. Opinion Poll about the Need for a Skill Development. Faculty of Economics.

Table 1. Distribution of sample by course, degrees and experience, by sex and total

asymmetry or imbalance in the assignment of answers between the options is proved in the estimated mean values and therefore in the differentials of those values for both questions (tables with the average values to facilitate the reading haven't been presented, although they are available in the quoted text). Thus, the average obtained is higher than 3.2 regarding the importance in the working environment, reaching even 4.3. The averages fluctuated between 2.1 and 3.4 regarding the degree of training as we can see in the Figure 1 attached, which clearly shows the difference in the average values between the two series.

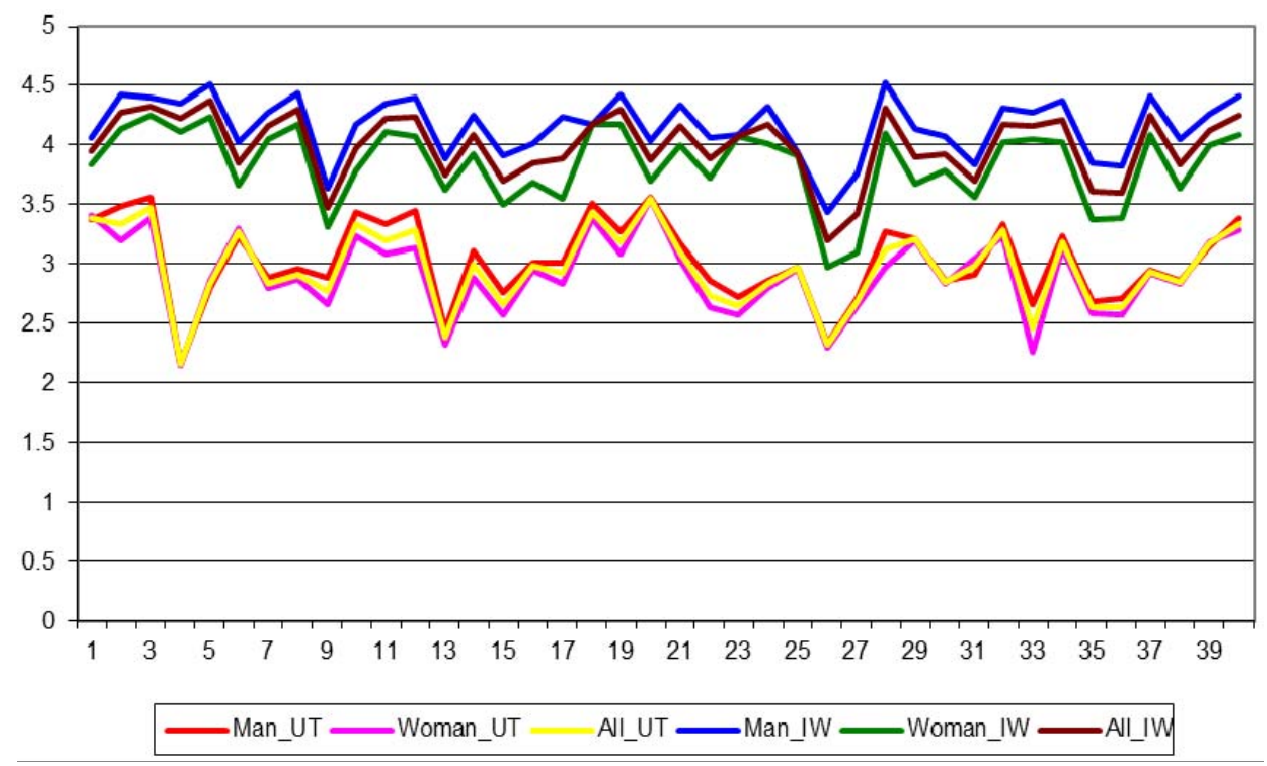

SOURCE: Personal Compilation. Opinion Poll about the Need for a Skill Development. Faculty of Economics and Business.

Fig. 1. Average values: Importance in the working environment/Training at University, total and by sex 
Furthermore, the different segmentations confirm the general rule already mentioned: the average rating that students assigned to the importance of the different skills in the working environment was greater than the degree of skill development they stated they have, regarding all students and segmented by sex, being in both cases the average values assigned by men higher than those assigned by women. Fluctuations were wider in the series related to the importance of skills in the working environment (_IW) than in the perception of the degree of formation gained during university training (_UT): in other words, students had a more uniform opinion about how important university training was for their skill development and they presented a higher variability in the assessment of the importance of the skill development in their working environment. Similarly, when the sample was segmented according to the year students were enrolled, the average assessment of the degree of skill development was higher among those who were in their fifth year than among those who were still in their fourth year. Nonetheless, the opposite occurred regarding the importance of the skill development in the working environment. In the segmentation, students with previous work experience conferred more importance to skill development than those who did not have it. Previous work experience also helped to change the perception they had, which helped to adjust their assessments and hence reduce the differential between the averages of both questions.

In brief, tables A2 and A3 appearing in the Annex show the results of the descriptive analysis of this piece of work, that is, the differential between the two questions in the average assessment of the students who were consulted, for all the skills, reflected in the figures 2 and 3, attached in the text. In general, the average assessment of men was slightly higher than the average assessment of women, nearly in all the skills, regardless of the fact they had or not professional experience or in which year, fourth or fifth, they were enrolled. Results were similar in both questions: the one about the importance they think skills have in their working environment and the one about to what extent they think university training contributes to their skill development. This fact determines a positive differential in the averages estimated, with a wide value range depending on skills, for the total population and by sex, and it was higher for men than for women, with few exceptions. Thus, for the total population, the differential estimated was lower when there was work experience. The reason could be that the student would have done or would be doing an internship or that maybe the student would have had a temporary employment, with a few exceptions not very significant.

In short, figure 2 (and table A2 in the Annex) shows the differential averages for the different skills and for the totals and subsamples by sex, according they had or not work experience. It could be observed that there was quite general pattern with a lower profile in the differential for the subsamples of women with work experience, a fact that meant a better adjustment and therefore a lower differential between the assessment they did about how important was skill development in their work environment and the degree of the skill development. There was a higher profile of men who stated that they did not have work experience, an aspect that suggested greater imbalances in the assessments. In fact, exceptions to this pattern were found in the subsamples of students with work experience, only in the skill "Negotiate efficiently" and among those who did not have work experience in "Organisation and Planning", "Oral and written communication in first language", "Ability to make yourself understood", "Work well under pressure", "Manage effectively your time", "Leadership" and "Trade efficiently". 


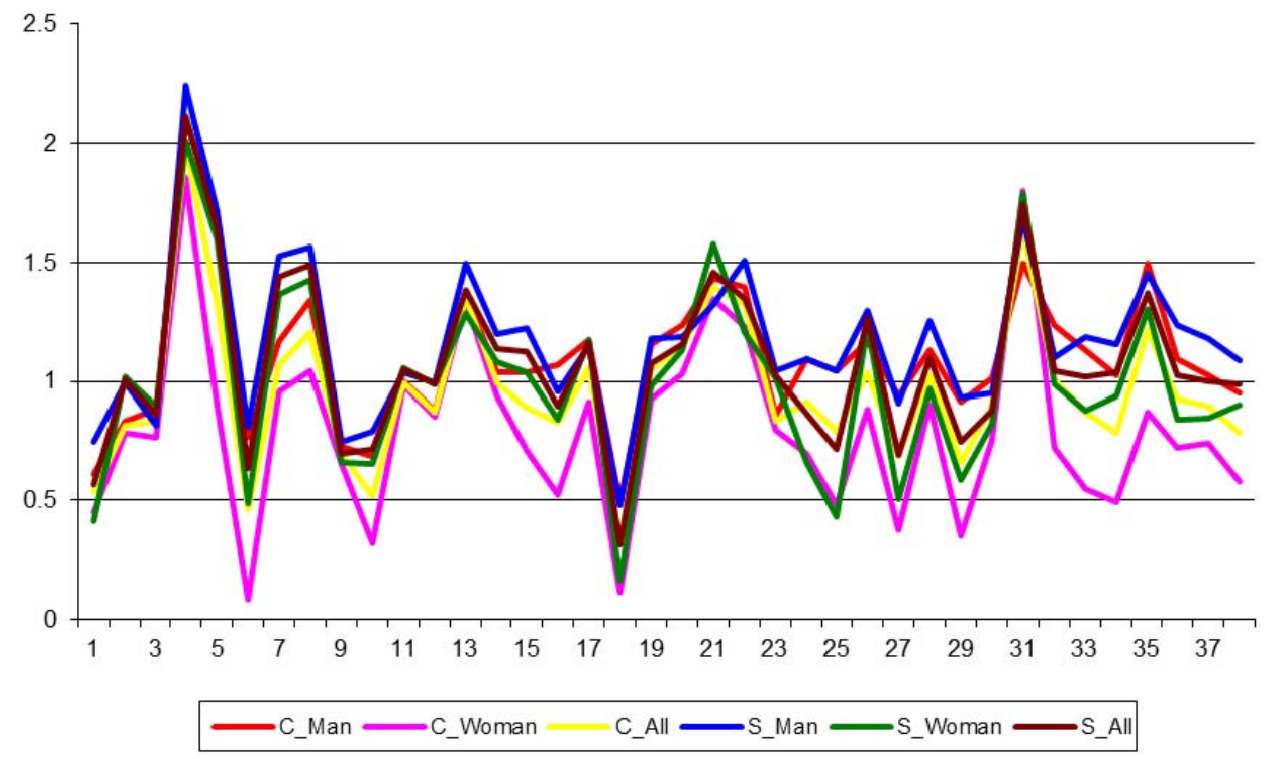

SOURCE: Personal Compilation. Opinion Poll about the Need for a Skill Development. Faculty of Economics and Business

Fig. 2. Differential importance in the work environment - Training at University, total and by sex, according the students have or not work experience

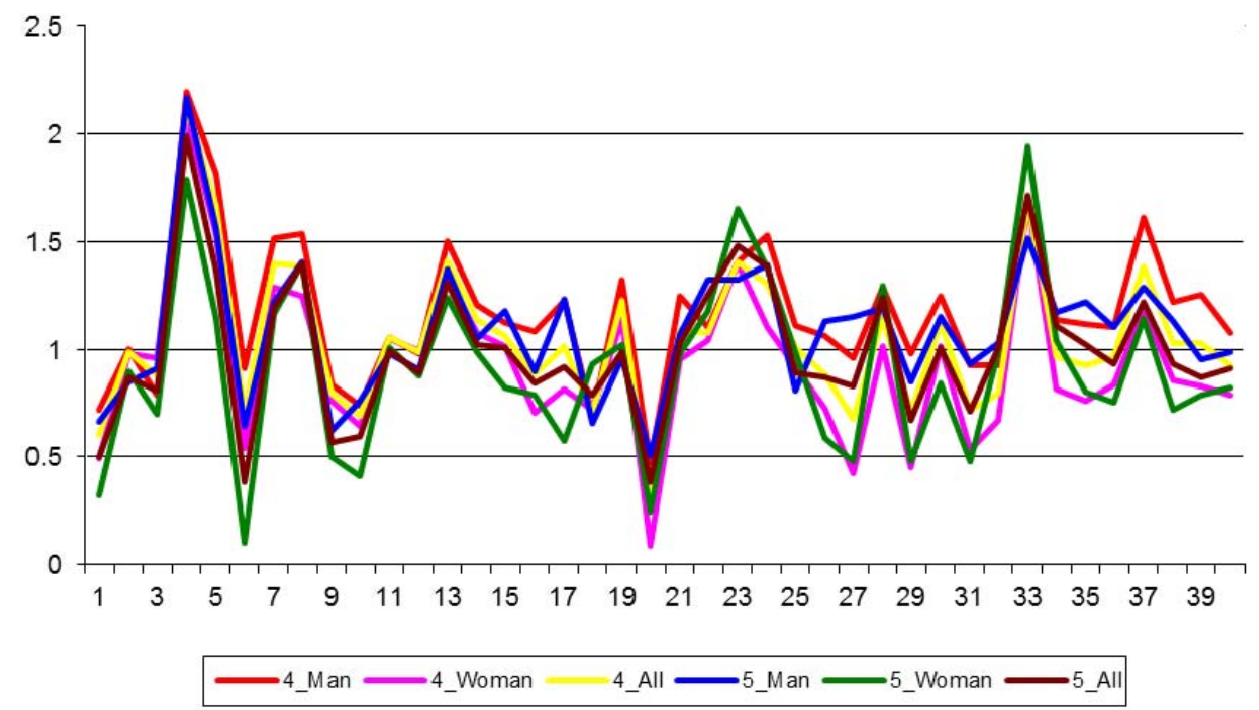

SOURCE: Personal Compilation. Opinion Poll about the Need for a Skill Development. Faculty of Economics and Business

Fig. 3. Differential Importance in the working place - Training at University, total and by sex, according they are in the fourth or fifth year of the degree 
Figure 3 (and table A3 of the Annex) above shows this differential for the different skills, by total and subsample by sex, according to the year in which the student was enrolled with a quite similar pattern to the one seen in the previous segmentation by work experience. This is because this experience increased every year, with a lower profile in the differential for the subsample of women who were enrolled in their fifth year and higher in men who were enrolled in their fourth year although this profile was not so clear, with some crossings in the assessments.

These descriptive results support the hypothesis already expressed previously: having previous work experience, either through temporary contracts or through internships, improves the perception of a higher degree of skill development, as they pass their fourth year and enrol in their fifth year and they are finishing their university training. Therefore, the studied differential reduces, and the adjustment between the assessments they did about the importance in the work environment and the degree of skill development achieved improves considerably. This information, considered to be quite important, should be interpreted as an indicator showing in which direction teaching should be addressed: the student, who has to learn specific knowledge of this subject, has to develop also some basic generic skills, including systemic, personal and instrumental ones. The added value that brings this information will result in a better teaching and research activity of the professor, with a greater understanding of the skill profile of students. This new situation will result in practical activities that will let students and future graduates be more trained for the work environment they are going to enter in a short period of time.

Some pieces of work which continue with this approach and which are being written in other universities should be pointed out in order to find the needs and the skill model of their students and graduates. An instance of this is the empirical study written by Ramírez and Velásquez (2010) that confirms the existence of differences between the skill profile for employment assessed by students from an academic point of view and professor and skill profile assessed by graduates and employers from a work point of view. In this way, the first ones consider that instrumental skills, such as languages and office automation, that is, the ones they cannot use correctly, are more important than the systemic skills, related to social, organizational and work management areas.

\section{Conclusion}

The aim of this piece of work was to reflect (or in this case make you think) about some of the methodological aspects of the study and teaching in Economic Analysis nowadays, recovering some lessons given by important scholars, mainly Professor Robinson, in an historic moment for the Spanish University which has completed the process of European convergence as a regenerating element of its university training and their necessary adaptation to an academic world which is a work, social, changing and globalized word.

The starting point for this piece of work is to use again the box of tricks with which all economists have graduated at our universities, and reopen it to assess one more time its usefulness in an uncertain, open and changing world that in some cases depends too much on new technologies, characterized by the inter/multi/transdisciplinarity analysis and the necessary scientific cooperation between the different disciplines in order to tackle and solve the social and economic problems that society and institutions have nowadays. This box of 
tricks refers to a set of basic concepts, categories, analytical instruments that all economists should know how to use, as well as their prospects, scopes and the adaptation to this period of time.

Nowadays, we work, teach/learn and do research collectively, connected through the Internet, with teaching tools that range from e-learning platforms to web-quest, where students download all kinds of teaching materials (text, audio or video) in order to make progress in their learning process. For many people, this is the learning economy (Lundvall and Johnson, 1994, Archibugi and Lundvall, 2001), whose key is the ability to learn from people, organisations, networks and regions, learn to present other criteria and scopes and to use the potential of new technologies to completely change new processes, ideas, products and so on.

Therefore, an economist should not merely know the proper use of tools as analytical instruments. Instead, those tools, as many important economists have stated, should be complemented with other aspects that are suitable to develop a dose of creativity that let us find the solution to the important economic problems that our society and institutions have to face up. In this context, Krueger et al. (1991, cited in Streeten, 2007, p. 57) state, in relation to Economics postgraduate studies in the U.S.A., that the main weakness of these studies was not the excessive use of Mathematics, but insufficient emphasis on links between theoretical and econometric tools and the problems of the real World. In words of Streeten (2007, p. 42), according to the Petition to Reform Undergraduate Education signed by more than 460 professors who are involved in hiring new professors who teach economy to undergraduate students in the U.S.A., the selected economists should have an understanding of the economic debates and the literature of the previous 20 years,...with a strong knowledge of the models that are taught to students, knowledge of the economic institutions and about the role those carry out in the economy, ability to communicate both verbally and in prose the main ideas of the Microeconomics and the Macroeconomics, knowledge of alternative approaches in economics and ability to contrast them and also knowledge of Econometrics and the limits of their proofs. All graduates in Economics in this country and in this economic system should therefore meet these requirements perfectly, which consist not only of technical knowledge but also include several skills.

As for the need for higher doses of creativity to face economic problems above mentioned, this creativity is institutionally considered as the driving force for innovation and a key factor for the development of personal, work, business and social skills of people, as well as the social welfare (text extracted of the Decision number 1350/2008/EC OF European Parliament and of the Council, of 16, December 2008, Official Journal of the European Union). Therefore, according to Perinat (2004), being a competent professional means not only knowing (having a theoretical or specific knowledge), but also knowing-how (practical knowledge) and knowing how to be (providing axiological professional attitudes).

Professors know that changes in the methodological didactic environment are aimed at only one objective: contributing to improve the quality of education. For this to be done, the activity of the professor-tutor-orchestrator-companion should be "redefined", and they must learn continuously the new technological applications which lead to "relearn" professional teaching practice "doing it". One important factor is to have a better and greater knowledge of the effectiveness of the classes given, through multiple indicators 
(assessment of educational attributes, causes of absenteeism, relationship between attendance and performance, incidence of tutoring in professor assessment, consideration of sex in these assessments, imbalances in the skill development of students and so on). For this purpose, professors can and should combine their teaching activities with research in order to find out strengths and weaknesses and generate with this a feedback process that improves our facet as professors as well as putting research about teaching at the disposal of the teaching activity itself, no matter which discipline nor which area of expertise, given the heterogeneity of students, subjects, disciplines, professors and degrees.

From this point of view, this piece of work has combined the methodological aspects of economic studies, the requirements of professional economists and a skill model balanced with their work environment. The empirical analysis let us highlight as a general rule for all students consulted that the average assessment given by students about the different segmentation proposals at work is higher than the degree of skill development they state they have. This fact determines always a positive differential between both values. Furthermore, in the segmentation by year in which the student is enrolled, the average assessment of the degree of development or preparation is generally higher among those students who are in their fifth year than those who are in their fourth year, although it is just the opposite when we talk about its importance in the work environment. It should be pointed out that, as a general rule and for the total of students, the average assessment of the degree of the development of skills at university and of its importance in the work environment is higher when students have previous work experience. In this way, the estimated differential for the different skills shows a quite general pattern with lower values in the differential for the subsamples of women with work experience, a fact that implies a better adjustment between the assessments they do of the importance in the work environment and of the degree of skill development, and the higher values for men who do not have previous work experience.

Professors should not only bear in mind what happens in a classroom but they also should think about the professional world students are going to enter, in order to facilitate the adaptation of these students to their changing, globalized and multidisciplinary work environments with creative vision which will let them solve problems, with greater specific knowledge and with a demonstrable background. Professors should have knowledge of other disciplines, how to deal with the different scientific areas, learn from other approaches because as Myrdal (1975; 2002 p. 70) states, in fact, problems are not economic, sociological, ecologic or psychological, but "they are all mixed and composite". We should open our classical box of tricks in order to achieve that those (many people) who think that the person "who is just an economist is a bad economist" (Streeten, 2007, p. 36) change their mind.

\section{Acknowledgment}

The data used come from the Project of Innovation and Improvement of the Education Quality: Educational plan aimed to improve the teaching of generic skills o students. From university to the work environment, financed by the Complutense University of Madrid (UCM). Thanks are due to C. Ionita, who tabulated the questions and did a first descriptive approach to the data.

The translation of the chapter was made by Guirado López, P. and Sánchez Moya, A. 


\section{Annex}

\begin{tabular}{|c|c|c|c|c|c|c|c|c|c|c|}
\hline \multirow{3}{*}{ Skills } & \multicolumn{5}{|c|}{ University Training (UT) } & \multicolumn{5}{|c|}{ Importance at Work ( IW) } \\
\hline & \multicolumn{5}{|c|}{ Distribution of frequencies (\%) } & \multicolumn{5}{|c|}{ Distribution of frequencies $(\%)$} \\
\hline & 1 & 2 & 3 & 4 & 5 & 1 & 2 & 3 & 4 & 5 \\
\hline Analytical thinking and Ability to Synthesis & 2.25 & 12.16 & 38.74 & 38.29 & 8.56 & 0.90 & 4.05 & 20.50 & 48.65 & 25.90 \\
\hline Organization and Planning & 2.93 & 22.30 & 28.15 & 31.08 & 15.54 & 0.90 & 1.80 & 9.91 & 43.24 & 44.14 \\
\hline Oral and written communication in the mother tongue & 4.05 & 13.51 & 31.98 & 31.98 & 18.24 & 0.45 & 1.80 & 12.61 & 35.59 & 49.55 \\
\hline Oral and written communication in a foreign language & 38.29 & 28.60 & 17.79 & 9.91 & 5.41 & 2.25 & 3.15 & 14.86 & 28.83 & 50.90 \\
\hline Ability to use computer tools & 11.71 & 29.05 & 31.76 & 19.37 & 8.11 & 0.68 & 1.13 & 8.78 & 39.19 & 50.23 \\
\hline Ability to look for information in several resources & 4.05 & 19.59 & 31.76 & 34.46 & 10.14 & 0.68 & 4.50 & 26.58 & 46.17 & 22.07 \\
\hline Resolving conflicts or solving problems & 10.36 & 27.03 & 34.91 & 23.42 & 4.28 & 1.13 & 3.15 & 15.09 & 40.32 & 40.32 \\
\hline Making decisions & 10.81 & 21.40 & 39.41 & 22.52 & 5.86 & 0.45 & 2.93 & 10.36 & 38.29 & 47.97 \\
\hline Knowledge of other areas and disciplines & 13.29 & 28.60 & 30.41 & 22.97 & 4.73 & 2.03 & 11.49 & 36.49 & 37.39 & 12.61 \\
\hline Gaining new knowledge quickly & 3.60 & 15.99 & 36.26 & 32.43 & 11.71 & 0.23 & 3.83 & 22.30 & 45.50 & 28.15 \\
\hline Ability to make yourself understood/to communicate & 4.73 & 18.69 & 36.94 & 31.08 & 8.56 & 0.23 & 2.93 & 14.86 & 37.61 & 44.37 \\
\hline Working in a multidisciplinary team & 5.64 & 15.58 & 33.18 & 35.44 & 10.16 & 0.45 & 2.25 & 13.74 & 40.32 & 43.24 \\
\hline Working in an international context & 26.35 & 31.08 & 24.77 & 13.74 & 4.05 & 3.60 & 6.31 & 25.23 & 40.99 & 23.87 \\
\hline $\begin{array}{l}\text { Ability to manage personal relationships and } \\
\text { interpersonal communication }\end{array}$ & 7.88 & 22.07 & 38.74 & 24.77 & 6.53 & 0.90 & 2.25 & 17.12 & 46.62 & 33.11 \\
\hline Working in different and multicultural environm & 18.24 & 29.95 & 25.90 & 19.37 & 6.53 & 3.38 & 8.33 & 27.48 & 36.26 & 24.55 \\
\hline Critical and self-critical capacity & 6.98 & 25.00 & 37.39 & 24.32 & 6.31 & 1.13 & 5.41 & 25.68 & 43.02 & 24.77 \\
\hline Ethical commitment at work & 13.74 & 20.27 & 36.04 & 20.27 & 9.68 & 3.83 & 4.95 & 22.07 & 36.49 & 32.66 \\
\hline Working well under pressure & 7.66 & 11.71 & 29.73 & 30.86 & 20.05 & 1.58 & 3.15 & 14.64 & 36.94 & 43.69 \\
\hline Managing effectively your time & 9.91 & 17.79 & 33.11 & 23.20 & 15.99 & 0.90 & 2.25 & 9.68 & 40.09 & 47.07 \\
\hline Self-learning & 3.83 & 11.49 & 27.70 & 39.86 & 17.12 & 1.13 & 3.83 & 25.45 & 46.40 & 23.20 \\
\hline Adaptation to new situations & 6.08 & 20.05 & 39.41 & 26.80 & 7.66 & 0.23 & 2.70 & 15.09 & 44.37 & 37.61 \\
\hline Creativity & 14.64 & 25.68 & 35.59 & 19.14 & 4.95 & 1.80 & 5.63 & 20.72 & 45.27 & 26.58 \\
\hline Leadership & 15.77 & 31.31 & 31.76 & 14.86 & 6.31 & 1.13 & 3.60 & 18.24 & 39.86 & 37.16 \\
\hline $\begin{array}{l}\text { Initiative and entrepreneurial spirit : finding new } \\
\text { ideas and solutions }\end{array}$ & 10.36 & 28.38 & 33.78 & 22.97 & 4.50 & 0.90 & 2.70 & 15.32 & 40.77 & 40.32 \\
\hline Motivation by quality & 9.68 & 22.30 & 36.49 & 24.77 & 6.76 & 0.45 & 4.95 & 25.23 & 40.32 & 29.05 \\
\hline Environmental sensitivity & 31.53 & 28.60 & 21.40 & 13.29 & 5.18 & 7.66 & 20.27 & 30.18 & 28.15 & 13.74 \\
\hline Sensitivity to social issues & 18.02 & 27.03 & 30.18 & 18.47 & 6.31 & 4.50 & 15.32 & 30.63 & 32.43 & 17.12 \\
\hline Putting knowledge into practice & 9.68 & 18.02 & 33.56 & 28.15 & 10.59 & 0.68 & 1.58 & 14.41 & 33.11 & 50.23 \\
\hline Ability to look for information and research & 5.86 & 18.92 & 31.53 & 36.04 & 7.66 & 0.90 & 3.60 & 23.42 & 48.87 & 23.20 \\
\hline Design and management of projects & 11.71 & 23.20 & 38.29 & 22.07 & 4.73 & 1.35 & 4.73 & 20.50 & 47.07 & 26.35 \\
\hline Ability to popularize economic issues & 7.88 & 21.85 & 40.32 & 24.55 & 5.41 & 1.13 & 6.08 & 34.01 & 39.64 & 19.14 \\
\hline Present products, ideas or reports in public & 6.08 & 17.34 & 31.31 & 32.88 & 12.39 & 0.90 & 3.15 & 18.69 & 32.88 & 44.37 \\
\hline Trade efficiently & 26.13 & 26.13 & 27.48 & 16.22 & 4.05 & 1.35 & 3.38 & 12.84 & 42.57 & 39.86 \\
\hline Writing reports or documents & 9.01 & 18.02 & 30.63 & 31.08 & 11.26 & 1.13 & 3.60 & 11.71 & 40.77 & 42.79 \\
\hline Emotional self-awareness & 19.59 & 25.00 & 32.66 & 17.57 & 5.18 & 3.60 & 6.08 & 32.66 & 41.44 & 16.22 \\
\hline Emotional self-assessment & 19.14 & 26.35 & 29.73 & 20.72 & 4.05 & 3.83 & 6.98 & 34.23 & 35.81 & 19.14 \\
\hline Self-confidence & 15.54 & 22.07 & 27.25 & 24.10 & 11.04 & 1.35 & 4.05 & 12.61 & 32.43 & 49.55 \\
\hline Empathy & 13.96 & 22.52 & 33.78 & 24.10 & 5.63 & 2.03 & 6.08 & 26.80 & 36.04 & 29.05 \\
\hline Guidance to the achievement/success & 8.11 & 17.57 & 32.66 & 32.66 & 9.01 & 0.90 & 2.48 & 16.44 & 42.79 & 37.39 \\
\hline $\begin{array}{l}\text { Expressing ideas and fighting for rights without } \\
\text { attacking }\end{array}$ & 8.33 & 15.99 & 28.15 & 29.28 & 18.24 & 1.35 & 1.80 & 14.19 & 35.81 & 46.85 \\
\hline
\end{tabular}

SOURCE: Opinion Poll about the Need for a Skill Development. Faculty of Economics and Business. Personal Compilation.

Table A1. Distribution of skill frequencies, by degree of university training and importance in the work environment 


\begin{tabular}{|c|c|c|c|c|c|c|}
\hline \multirow{3}{*}{ Skills } & \multicolumn{6}{|c|}{$\begin{array}{c}\text { Differential average values } \\
\text { Importance at work - University Training }\end{array}$} \\
\hline & \multicolumn{3}{|c|}{$\begin{array}{c}\text { With professional } \\
\text { experience }\end{array}$} & \multicolumn{3}{|c|}{$\begin{array}{c}\begin{array}{c}\text { Without professional } \\
\text { experience }\end{array} \\
\end{array}$} \\
\hline & Man & Woman & All & Man & Woman & All \\
\hline Analytical thinking and Ability to Synthesis & 0.612 & 0.449 & 0.539 & 0.748 & 0.413 & 0.569 \\
\hline Organization and Planning & 0.836 & 0.782 & 0.812 & 0.993 & 1.019 & 1.007 \\
\hline Oral and written communication in the mother tongue & 0.882 & 0.768 & 0.832 & 0.815 & 0.897 & 0.859 \\
\hline Oral and written communication in a foreign language & 2.106 & 1.855 & 1.994 & 2.237 & 2.013 & 2.117 \\
\hline Ability to use computer tools & 1.694 & 0.899 & 1.337 & 1.711 & 1.593 & 1.648 \\
\hline Ability to look for information in several resources & 0.765 & 0.087 & 0.461 & 0.808 & 0.484 & 0.634 \\
\hline Resolving conflicts or solving problems & 1.165 & 0.957 & 1.071 & 1.526 & 1.368 & 1.441 \\
\hline Making decisions & 1.341 & 1.044 & 1.208 & 1.563 & 1.426 & 1.489 \\
\hline Knowledge of other areas and disciplines & 0.729 & 0.652 & 0.695 & 0.748 & 0.658 & 0.700 \\
\hline Gaining new knowledge quickly & 0.682 & 0.319 & 0.52 & 0.793 & 0.651 & 0.718 \\
\hline Ability to make yourself understood/to communicate & 1 & 0.985 & 0.993 & 1.037 & 1.058 & 1.048 \\
\hline Working in a multidisciplinary team & 0.878 & 0.855 & 0.868 & 0.993 & 0.987 & 0.99 \\
\hline Working in an international context & 1.365 & 1.334 & 1.351 & 1.496 & 1.284 & 1.383 \\
\hline $\begin{array}{l}\text { Ability to manage personal relationships and interpersonal } \\
\text { communication }\end{array}$ & 1.035 & 0.942 & 0.993 & 1.2 & 1.084 & 1.138 \\
\hline Working in different and multicultural environments & 1.035 & 0.71 & 0.889 & 1.222 & 1.039 & 1.124 \\
\hline Critical and self-critical capacity & 1.07 & 0.522 & 0.825 & 0.956 & 0.839 & 0.893 \\
\hline Ethical commitment at work & 1.165 & 0.682 & 0.949 & 1.274 & 0.735 & 0.986 \\
\hline Working well under pressure & 0.611 & 0.55 & 0.585 & 0.718 & 0.916 & 0.824 \\
\hline Managing effectively your time & 1.177 & 0.913 & 1.059 & 1.149 & 1.174 & 1.162 \\
\hline Self-learning & 0.494 & 0.116 & 0.325 & 0.482 & 0.167 & 0.314 \\
\hline Adaptation to new situations & 1.153 & 0.928 & 1.052 & 1.178 & 0.981 & 1.073 \\
\hline Creativity & 1.235 & 1.029 & 1.143 & 1.185 & 1.129 & 1.155 \\
\hline Leadership & 1.435 & 1.348 & 1.396 & 1.326 & 1.574 & 1.459 \\
\hline $\begin{array}{l}\text { Initiative and entrepreneurial spirit : finding new ideas and } \\
\text { solutions }\end{array}$ & 1.4 & 1.232 & 1.324 & 1.511 & 1.206 & 1.348 \\
\hline Motivation by quality & 0.859 & 0.797 & 0.831 & 1.044 & 1.013 & 1.027 \\
\hline Environmental sensitivity & 1.094 & 0.695 & 0.915 & 1.096 & 0.659 & 0.862 \\
\hline Sensitivity to social issues & 1.047 & 0.478 & 0.792 & 1.044 & 0.432 & 0.717 \\
\hline Putting knowledge into practice & 1.165 & 0.884 & 1.039 & 1.296 & 1.239 & 1.266 \\
\hline Ability to look for information and research & 0.941 & 0.377 & 0.688 & 0.911 & 0.503 & 0.693 \\
\hline Design and management of projects & 1.129 & 0.899 & 1.026 & 1.252 & 0.968 & 1.1 \\
\hline Ability to popularize economic issues & 0.917 & 0.348 & 0.662 & 0.933 & 0.587 & 0.748 \\
\hline Present products, ideas or reports in public & 1.012 & 0.753 & 0.896 & 0.949 & 0.82 & 0.879 \\
\hline Trade efficiently & 1.494 & 1.797 & 1.63 & 1.689 & 1.787 & 1.742 \\
\hline Writing reports or documents & 1.236 & 0.725 & 1.006 & 1.103 & 0.987 & 1.042 \\
\hline Emotional self-awareness & 1.129 & 0.55 & 0.87 & 1.185 & 0.877 & 1.02 \\
\hline Emotional self-assessment & 1.023 & 0.493 & 0.785 & 1.155 & 0.942 & 1.041 \\
\hline Self-confidence & 1.494 & 0.869 & 1.215 & 1.452 & 1.303 & 1.373 \\
\hline Empathy & 1.094 & 0.725 & 0.928 & 1.237 & 0.839 & 1.024 \\
\hline Guidance to the achievement/success & 1.023 & 0.74 & 0.896 & 1.178 & 0.845 & 1 \\
\hline Expressing ideas and fighting for rights without attacking & 0.953 & 0.579 & 0.786 & 1.089 & 0.903 & 0.990 \\
\hline AVERAGE INDICATOR & 1.097 & 0.801 & 0.965 & 1.166 & 0.993 & 1.074 \\
\hline
\end{tabular}

SOURCE: Opinion Poll about the Need for a Skill Development. Faculty of Economics and Business. Personal Compilation.

Table A2. Differential: Importance at Work - University Training, by experience, sex and total 


\begin{tabular}{|c|c|c|c|c|c|c|}
\hline \multirow{3}{*}{ Skills } & \multicolumn{6}{|c|}{$\begin{array}{c}\text { Differential average values } \\
\text { Importance at Work - University Training }\end{array}$} \\
\hline & \multicolumn{3}{|c|}{ 4th year } & \multicolumn{3}{|c|}{5 th year } \\
\hline & Man & Woman & All & Man & Woman & All \\
\hline Analytical thinking and Ability to Synthesis & 0.719 & 0.492 & 0.6 & 0.667 & 0.322 & 0.503 \\
\hline Organization and Planning & 1 & 0.978 & 0.988 & 0.848 & 0.9 & 0.873 \\
\hline Oral and written communication in the mother tongue & 0.785 & 0.963 & 0.878 & 0.909 & 0.7 & 0.81 \\
\hline Oral and written communication in a foreign language & 2.198 & 2.082 & 2.138 & 2.172 & 1.789 & 1.989 \\
\hline Ability to use computer tools & 1.818 & 1.537 & 1.67 & 1.566 & 1.144 & 1.365 \\
\hline Ability to look for information in several resources & 0.909 & 0.538 & 0.713 & 0.647 & 0.1 & 0.386 \\
\hline Resolving conflicts or solving problems & 1.52 & 1.291 & 1.4 & 1.222 & 1.166 & 1.196 \\
\hline Making decisions & 1.537 & 1.246 & 1.385 & 1.404 & 1.4 & 1.402 \\
\hline Knowledge of other areas and disciplines & 0.834 & 0.761 & 0.796 & 0.626 & 0.5 & 0.566 \\
\hline Gaining new knowledge quickly & 0.743 & 0.642 & 0.69 & 0.758 & 0.411 & 0.593 \\
\hline Ability to make yourself understood/to communicate & 1.058 & 1.052 & 1.054 & 0.98 & 1.011 & 0.995 \\
\hline Working in a multidisciplinary team & 0.984 & 0.992 & 0.988 & 0.905 & 0.878 & 0.892 \\
\hline Working in an international context & 1.505 & 1.336 & 1.415 & 1.373 & 1.245 & 1.312 \\
\hline $\begin{array}{l}\text { Ability to manage personal relationships and interpersonal } \\
\text { communication }\end{array}$ & 1.207 & 1.075 & 1.137 & 1.051 & 0.988 & 1.022 \\
\hline Working in different and multicultural environments & 1.124 & 1.015 & 1.066 & 1.182 & 0.822 & 1.011 \\
\hline Critical and self-critical capacity & 1.082 & 0.709 & 0.886 & 0.899 & 0.789 & 0.846 \\
\hline Ethical commitment at work & 1.231 & 0.813 & 1.012 & 1.232 & 0.578 & 0.921 \\
\hline Working well under pressure & 0.694 & 0.717 & 0.706 & 0.656 & 0.933 & 0.789 \\
\hline Managing effectively your time & 1.323 & 1.142 & 1.227 & 0.959 & 1.022 & 0.989 \\
\hline Self-learning & 0.471 & 0.09 & 0.271 & 0.506 & 0.245 & 0.381 \\
\hline Adaptation to new situations & 1.248 & 0.955 & 1.094 & 1.071 & 0.978 & 1.026 \\
\hline Creativity & 1.107 & 1.045 & 1.074 & 1.323 & 1.178 & 1.254 \\
\hline Leadership & 1.405 & 1.403 & 1.404 & 1.323 & 1.656 & 1.482 \\
\hline $\begin{array}{l}\text { Initiative and entrepreneurial spirit: finding new ideas and } \\
\text { solutions }\end{array}$ & 1.529 & 1.105 & 1.306 & 1.394 & 1.378 & 1.387 \\
\hline Motivation by quality & 1.108 & 0.918 & 1.008 & 0.808 & 0.989 & 0.894 \\
\hline Environmental sensitivity & 1.066 & 0.724 & 0.887 & 1.131 & 0.589 & 0.873 \\
\hline Sensitivity to social issues & 0.959 & 0.425 & 0.678 & 1.152 & 0.478 & 0.831 \\
\hline Putting knowledge into practice & 1.29 & 1.015 & 1.146 & 1.192 & 1.3 & 1.243 \\
\hline Ability to look for information and research & 0.984 & 0.455 & 0.706 & 0.849 & 0.478 & 0.672 \\
\hline Design and management of projects & 1.248 & 1.015 & 1.126 & 1.152 & 0.844 & 1.006 \\
\hline Ability to popularize economic issues & 0.926 & 0.537 & 0.721 & 0.93 & 0.477 & 0.714 \\
\hline Present products, ideas or reports in public & 0.926 & 0.672 & 0.792 & 1.031 & 0.989 & 1.01 \\
\hline Trade efficiently & 1.694 & 1.686 & 1.69 & 1.516 & 1.945 & 1.719 \\
\hline Writing reports or documents & 1.141 & 0.813 & 0.968 & 1.172 & 1.044 & 1.112 \\
\hline Emotional self-awareness & 1.115 & 0.762 & 0.929 & 1.222 & 0.8 & 1.021 \\
\hline Emotional self-assessment & 1.107 & 0.836 & 0.965 & 1.101 & 0.756 & 0.936 \\
\hline Self-confidence & 1.612 & 1.187 & 1.388 & 1.293 & 1.145 & 1.222 \\
\hline Empathy & 1.223 & 0.858 & 1.031 & 1.132 & 0.722 & 0.936 \\
\hline Guidance to the achievement/success & 1.256 & 0.828 & 1.031 & 0.95 & 0.789 & 0.873 \\
\hline Expressing ideas and fighting for rights without attacking & 1.075 & 0.791 & 0.925 & 0.99 & 0.822 & 0.91 \\
\hline AVERAGE INDICATOR & 1.169 & 0.938 & 1.047 & 1.082 & 0.908 & 0.999 \\
\hline
\end{tabular}

SOURCE: Opinion Poll about the Need for a Skill Development. Faculty of Economics and Business. Personal Compilation.

Table A3. Differential: Importance at Work - University Training, by year, sex and total 


\section{References}

ANECA (Agencia Nacional de Evaluación de la Calidad y Acreditación), (2004). Encuesta de Inserción laboral. Madrid.

Archibugi, D. and Lundvall, B.-A. (Eds) (2001). The Globalizing Learning Economy, Oxford University Press. ISBN 9780199241095

Carpintero, O. (1999). Economía y Ciencias de la Naturaleza: algunas consideraciones sobre el legado de Nicholas Georgescu-Roegen. ICE Revista de Economía n ${ }^{\circ} 779$, pps. 127142. ISSN 0019-977X. Ministerio de Industria Comercio y Turismo, Madrid.

Climent, J. B. (2010) Reflexiones sobre la Educación Basada en Competencias. Revista Complutense de Educación. Vol. 21 Núm. 1, pps. 91-106. ISSN 1130-2496. UCM, Madrid.

Gilbert, M. (2001). El profesor del siglo XXI: de transmisor de contenidos a guía del ciberespacio. I Encuentro internacional "La informática en las Universidades InfoUni'2001 (La Habana, Cuba). Reference: january, 2009. Available from http://tecnologiaedu.us.es/bibliovir/pdf/203.pdf

González, J. y Wagenaar, R. (2003). (Coord.) Tuning Educational Structures in Europe. Informe final. Fase I. ISBN: 84-7485-892-5. Universidad de Deusto. Bilbao Available from:

http://www.relint.deusto.es/TUNINGProject/spanish/doc_fase1/Tuning\%20Ed ucational.pdf

Gracia, E. e Iglesia, M. C. (2007). La coordinación y diseño de materiales multidisciplinares para el campus virtual, en el área del Análisis Económico, Proceedings of Libro Actas III, Campus virtual, UCM. Madrid. Pps, 38-50. Available from: http:/ / eprints.ucm.es/5646/1/III_JORNADAS_CAMPUS_VIRTUAL.pdf

Holmes, L. (2000) Questioning the skills agenda, in S. Fallows y C. Steven (comps.) Integrating key skills in higher education: Employability, transferable skills and learning for life. pps. 201-214. ISBN 9780749432652. Londres: Kogan Page LDT

Iglesia, M. C. (2006). Varios retos y un único destino en la adaptación de los contenidos de la Teoría Económica al nuevo contexto de enseñanza aprendizaje. El campus virtual como herramienta de apoyo docente. Aplicaciones Prácticas de la Convergencia Europea. Edita: Servicio de Publicaciones y Oficina de Convergencia, UEX. Badajoz, 2006. ISBN: 84-7723-746-8

Iglesia, M. C. (2007). Joan Robinson, Keynesiana de izquierdas, capítulo 10, Mujeres economistas. Coord. Perdices, L. y Gallego, E. Ecobook, (2007). Pps 315-348. ISBN: 978-84-96877-02-3. Madrid.

Iglesia, M. C. y Ionita, C. (2010). Percepción de la necesidad de un desarrollo competencial en los estudios de economía y administración de empresas. Documento de trabajo, Enero 2010, Instituto de Análisis Industrial y Financiero. UCM. Available from: http:/ / eprints.ucm.es/10860/1/documento_de_trabajo_CIV.pdf

Koopmans, T. C. (1957). Three Essays on the State of Economic Analysis, Mc Graw-Hill. ISBN 70353352 New York

Krueger, A. et al. (1991). Report of the Commission on Graduate Education in Economics, Journal of Economic Literature, 29, pps. 1035-1053.

Levý-Leboyer, C. (2001). Gestión de las competencias: cómo analizarlas, cómo evaluarlas, cómo desarrollarlas. Ed. Gestión 2000. ISBN: 8480886382, Barcelona 
Lundvall, B. A. and Johnson, B. (1994). The learning economy, Journal of Industry Studies, Vol. 1,No. 2, December 1994, pps. 23-42.

McClelland, D. C. (1973). Testing for competente rather than intelligence. American Psycologist, $\mathrm{n}^{\mathrm{o}} 28$, pps. 1-14

Myrdal, G. (1975). The unity of social sciences. Human Organization, 34, 4 pps. 327-31 (See in The Dynamics of Applied Anthropology in the Twentieth Century: The Malinowski Award Papers Society for Applied Anthropology, Cap 5, pps. 70-76 Oklahoma City 2002. Reference: september, 2011, Available from http://www.sfaa.net/malinowski/monograph/malinowski.pdf\#page=70)

Perinat, A. (2004). Conocimiento y educación superior. Nuevos horizontes para la universidad del siglo XXI. Ediciones Paidós Ibérica S.A. ISBN 84-493-31-1664-3 Barcelona, España.

Ramírez, K. M. y Velásquez, A. (2010). Valoración de las competencias para el empleo en los titulados universitarios. Proceedings of I Congreso Internacional virtual de Formación del profesorado. Available from:

congresos.um.es/cifop/cifop2010/paper/download/9831/9801 (3, 10, 2011)

Robinson, J. (1937) Introduction to the Theory of Employment. MacMillan (reedited in 1969), London, ISBN 0333043952,

(1953), "Disertación en Oxford por un economista de Cambridge", en Robinson, J, (1979), "Contribuciones a la Teoría Económica Moderna", , Siglo XXI, pps. 171-178, Madrid, ISBN 968-23-0527-6,

(1960), [1964] Essays in Economics Analysis. Macmillan, Londres, Ensayos sobre Análisis Económico. Ed. Fondo de Cultura Económica. México, ISBN 84-375-0021-4

(1964), [1966] Economic Philosophy., Londres; Filosofía Económica. Ed Gredos. Madrid. ISBN 84-249-2602-1

(1973) Collected Economic Papers, Vol IV. Ed. Basil Blackwell. Oxford ISBN: 0631144803

(1977) What Are the Questions?. Journal of Economic Literature, Vol. 15, Issue 4 (Dec.), pps.1618-1339

Samuelson, P. (1947). Foundations of Economic Analysis, Cambridge Mass: Harvard University Press, enlarged edition 1983. ISBN 0674313038

Sladogna, M. G. (2000), “Una mirada a la construcción de las competencias desde el sistema educativo. La experiencia Argentina." En: CINTERFOR-OIT. Competencias laborales en la formación profesional. Boletín Técnico Interamericano de Formación Profesional. No 149, ISSN: 02542439, pps. 109-134

Spenser, L. M. y Spenser, S. M. (1993). Competence at work, models for superior performance. New York. Ed. John Wilwy Sons Inc., ISBN 047154809X

Streeten, P. (2007). “Qué está mal en la Economía contemporánea?”, (initially published in Interdisciplinary Science Review 27,1, 2002 p13-24) Revista de Economía Institucional, vol 9, no 16 pps. 35-62. Available from:

http:/ / www.economiainstitucional.com/pdf/No16/pstreeten16.pdf

Szenberg, M. (1994). Grandes economistas de hoy. Debate Pensamiento, Madrid. ISBN 84-7444$825-5$

Wake, J., Dysthe, O. y Mjelstad, S. (2007). New and Changing Teacher Roles in Higher Education in a Digital Age. Educational Technology and Society. Vol. 1, n. ${ }^{\circ}$ 10, pps. $40-$ 51. 
Walsh, V y Gram, H. (1980). Classical and Neoclassical Theories of General Equilibrium, Oxford University Press, New York and Oxford. ISBN 0-19-502674-8, p. XI

Zamagni, S. (1986). Georgescu-Roegen, Nicholas, Eds. John Eatwell, Murray Milgate and Peter Newman. Palgrave Macmillan, 1987, The New Palgrave Dictionary, First Edition. vol. II, pps. 515-516. ISBN 0-333-52722-4 
(C) 2012 The Author(s). Licensee IntechOpen. This is an open access article distributed under the terms of the Creative Commons Attribution 3.0 License, which permits unrestricted use, distribution, and reproduction in any medium, provided the original work is properly cited. 